\title{
Monitoring the operational impact of insecticide usage for malaria control on Anopheles funestus from Mozambique Sonia LR Casimiro ${ }^{1}$, Janet Hemingway ${ }^{2}$, Brian L Sharp ${ }^{3}$ and Michael Coleman*2,3
}

Address: ${ }^{1}$ National Institute of Health, Av. Eduardo Mondlane/Salvador Allende, PO Box 264, Maputo, Mozambique, ${ }^{2}$ Liverpool School of Tropical Medicine, Pembroke Place, Liverpool, L3 5QA, UK and ${ }^{3}$ Malaria Research Programme, Medical Research Council, Ridge Road, Durban, South Africa

Email: Sonia LR Casimiro - slrcasimiro@yahoo.com.br; Janet Hemingway - hemingway@liverpool.ac.uk; Brian L Sharp - sharpb@mrc.ac.za; Michael Coleman* - mcoleman@mrc.ac.za

* Corresponding author

Published: 9 January 2008

Malaria Journal 2008, 7:8 doi:10.1 186/1475-2875-7-8

This article is available from: http://www.malariajournal.com/content/7/l/8

(C) 2008 Casimiro et al; licensee BioMed Central Ltd.

This is an Open Access article distributed under the terms of the Creative Commons Attribution License (http://creativecommons.org/licenses/by/2.0), which permits unrestricted use, distribution, and reproduction in any medium, provided the original work is properly cited.

Since publication of our article [1], we have been made aware of several errors in our article.

In the Background section, paragraph 4, the first sentence "Pyrethroids, although an excellent insecticide class for controlling malaria, are only available in formulations with an accredited residual life of up to four months" should read "Pyrethroids, although an excellent insecticide class for controlling malaria, are only available in formulations with an accredited residual life of between 3 to 6 months [2]."

In the Background section, paragraph 4, the last sentence "As pyrethroid resistance has been selected, several control programmes, including Angola, South Africa, Mozambique and Zambia have reverted back to using DDT." should read "As pyrethroid resistance has been selected, several control programmes, including South Africa and Mozambique have reverted back to using DDT. Where cross-resistance occurs as in Equatorial Guinea alternative insecticide groups are being used."

In the Background section, paragraph 5, the last sentence "The only confirmed report in African Anopheles of kdr outside West Africa comes from Kenya, where a different mutation occurs changing the same amino acid residue in the sodium channel [11]." should read "Until recently, the only confirmed report in African Anopheles of $\mathrm{kdr}$ outside West Africa came from Kenya, where a different
Received: 7 January 2008

Accepted: 9 January 2008 mutation occurs changing the same amino acid residue in the sodium channel [11]."

In the Results section, paragraph 2, the first sentence "Five of the twenty sites (Benfica, Boane..." should read"Six of the sixteen sites (Benfica, Boane...".

In the Results section, paragraph 3, "Significant increase in pyrethroid resistance was detected in Benfica, Boane, Catuane, Chokwe and Moamba $(\mathrm{p}<0.05)$. Other sites, e.g. Mahotas, also showed increases in pyrethroid resistance, although the significance of the rise is unknown as the sample sizes $(\mathrm{n}<30)$ were low. A significant decrease $(\mathrm{P}<0.001)$ in pyrethroid resistance was recorded at Catuane, where baseline mortality was $72.7 \%$ which increased to $100 \%$ susceptibility in 2006 ." should read "Significant decreases in pyrethroid resistance were detected in Benfica, Boane, Catuane, Chokwe and Moamba ( $<0.05)$. Other sites, e.g. Mafambisse, showed increases in pyrethroid resistance, although the significance of the rise is unknown as the sample sizes $(\mathrm{n}<30)$ were low."

In addition the legend of Table 1 should read.

Table 1. WHO susceptibility test results on 1-3 day old F1 An. funestus from 16 localities in Mozambique 2006 data with Chi square comparisons to six of the study sites from the original 1999 base line survey. (- No data available) 
Table I: WHO susceptibility test results on I-3 day old FI An. Funestus from I 6 localities in Mozambique 2006 data with Chi square comparisons to 6 of the study sites from the original 1999 base line survey. (- No data available)

\begin{tabular}{|c|c|c|c|c|c|c|c|c|c|c|c|c|c|c|}
\hline \multirow[t]{3}{*}{ Locality } & \multicolumn{8}{|c|}{ Latest data 2002 to 2006} & \multicolumn{6}{|c|}{ Base line data from 1999} \\
\hline & \multicolumn{2}{|c|}{$\begin{array}{c}\text { Lambda-Cyhalothrin } \\
(0.05 \%)\end{array}$} & \multicolumn{2}{|c|}{$\begin{array}{l}\text { Delta-methrin } \\
(0.05 \%)\end{array}$} & \multicolumn{2}{|c|}{$\begin{array}{c}\text { Bendiocarb } \\
(0.01 \%)\end{array}$} & \multicolumn{2}{|c|}{ DDT (4\%) } & \multicolumn{2}{|c|}{$\begin{array}{l}\text { Lambda-Cyhalothrin } \\
(0.05 \%)\end{array}$} & \multicolumn{2}{|c|}{$\begin{array}{l}\text { Delta-methrin } \\
(0.05 \%)\end{array}$} & \multicolumn{2}{|c|}{$\begin{array}{c}\text { Bendiocarb } \\
(0.01 \%)\end{array}$} \\
\hline & $\mathrm{n}$ & $M$ & $\mathrm{n}$ & $M$ & $\mathrm{n}$ & M & $\mathrm{n}$ & $M$ & $\mathrm{n}$ & $M$ & $\mathrm{n}$ & M & $\mathrm{n}$ & $M$ \\
\hline Benfica & 240 & 94 & 138 & 90 & 220 & 99 & - & - & 19 & 100 & 16 & $43.8_{b}$ & 16 & 100 \\
\hline Boane & 426 & 92 & 25 & 96 & 372 & 98 & - & - & $74 I$ & $46.2_{\mathrm{b}}$ & 302 & $98.2_{\mathrm{a}}$ & 449 & 97.3 \\
\hline Catuane & 34 & 100 & - & - & - & - & - & - & 44 & $72.7_{b}$ & - & - & - & - \\
\hline Chibuto & 48 & 100 & - & - & 59 & 100 & - & - & - & - & - & - & - & - \\
\hline Chokwe & $13 \mid$ & 84 & - & - & 108 & 96 & - & - & 12 & $100 \mathrm{a}$ & - & - & 16 & $100_{a}$ \\
\hline Costa dol Sol & 70 & 81 & - & - & - & - & - & - & - & - & - & - & - & - \\
\hline Ferroviario & 21 & 76 & - & - & - & - & - & - & - & - & - & - & - & - \\
\hline Infulene & 14 & 100 & - & - & 38 & 100 & - & - & - & - & - & - & - & - \\
\hline Luis Cabral & 20 & 90 & - & - & - & - & - & - & - & - & - & - & - & - \\
\hline Mafambisse & 139 & 95 & - & - & 149 & 95 & 68 & 100 & 23 & $100_{a}$ & II & - & 22 & $100 \mathrm{a}$ \\
\hline Magude Sede & 238 & 88 & - & - & 150 & 100 & 23 & 100 & - & - & - & - & - & - \\
\hline Mahotas & 55 & 96 & 17 & 88 & 33 & 99 & - & - & - & - & - & - & - & - \\
\hline Matola & 261 & 90 & - & - & 209 & 100 & - & - & - & - & - & - & - & - \\
\hline Moamba & 29 & 83 & 25 & 96 & - & - & - & - & 87 & $75_{a}$ & 109 & $83.5_{a}$ & - & - \\
\hline Motaze & 435 & 83 & - & - & 300 & 97 & 14 & 100 & - & - & - & - & - & - \\
\hline Xinavane & 23 & 83 & - & - & 12 & 100 & - & - & - & - & - & - & - & - \\
\hline
\end{tabular}

$M=$ percentage mortality $_{a}=p>0.1_{b}=p<0.001$

The corrected version of Table 1 is given here.

We apologize for any inconvenience or confusion that this may have caused.

\section{References}

I. Casimiro S, Hemingway J, Sharp B, Coleman M: Monitoring the operational impact of insecticide usage for malaria control on Anopheles funestus from Mozambique. Malaria J 2007, 6: I 42.

2. WHO Pesticides Evaluation Scheme [http://www.who.int/ whopes/quality/en/]

Publish with Bio Med Central and every scientist can read your work free of charge

"BioMed Central will be the most significant development for disseminating the results of biomedical research in our lifetime. "

Sir Paul Nurse, Cancer Research UK

Your research papers will be:

- available free of charge to the entire biomedical community

- peer reviewed and published immediately upon acceptance

- cited in PubMed and archived on PubMed Central

- yours - you keep the copyright

Submit your manuscript here:

http://www.biomedcentral.com/info/publishing_adv.asp
BioMedcentral 